\title{
PEMANFAATAN NILAI BUDAYA CANDI BOROBUDUR DALAM PEMBELAJARAN SEJARAH
}

\author{
Oleh: Dedi Riyanto* \\ *Mahasiswa Program Studi Pendidikan Sejarah FKIP Universitas PGRI Palembang
}

\begin{abstract}
ABSTRAK
Candi Borobudur adalah salah satu monumen Budha yang terbesar di Indonesia adapun rumusan masalah dalam penelitian ini adalah bagaimana pemanfaatan nilai budaya candi Borobudur dalam pembelajaran sejarah dan tujuan penelitian ini adalah untuk mengetahui pemanfaatan nilai budaya candi Borobudur dalam pembelajaran sejarah. Metode dalam penelitian ini adalah metode deskriptif kualitatif. Teknik pengumpulan data melalui dokumentasi, observasi, dan wawancara. Teknik analisis data yaitu reduksi data, penyajian data dan penerikan kesimpulan. Berdasarkan hasil pembahasan dapat disampaikan bahwa candi Borobudur merupakan suatu banguan yang termegah di Indonesia dan di temukan sekitar abad ke VIII Masehi, sekaligus peninggalan agama Budha terbesar yang terdapat di pulau jawa maka dari itulah banyak sekali pemanfaatan nilai budaya yang terdapat di candi Borobudur dan sekaligus tempat mata pencaharian masyarakat Candi Borobudur.
\end{abstract}

Kata Kunci: Pemanfaatan Nilai Budaya, Candi Borobudur, Pembelajaran Sejarah.

\section{A. PENDAHULUAN}

Dalam agama Budha ada kepercayaan bahwa dunia ini tidak kekal, suatu ketika akan musnah dan akan muncul zaman baru. Setiap zaman mempunyai rangkaian Dhyani Budha-Dhyani Bodhisattna-Manusi Budha sendiri. Untuk zaman sekarang Dhyani Budhanya Avolkistesvara dan manusia Budhanya Cak Yamuni. Dalam rangkaian dunia yang tidak terbatas jumlahnya, lima dunia dan lima tiga serangkai ini masing-masing dianggap menepati mata angin sendiri-sendiri (Rahardjo, 2005:37).

Candi Borobudur adalah satu-satunya tempat pemujaan Budha yang terbesar di dunia, keberadaanya bagaikan suatu pernyataan dari batu yang serba kompleks indah dan arsitektur, mengenai banyak hal yang telah dikenal di Indonesia dan Asia Tenggara. Piramida bertingkat (step pyramid) susunan candi seperti limas telah dipakai sejak prasejarah di Asia dan Polynesia. Borobudur sebagai suatu kesaksian yang terus-menerus terhadap dan sebuah manifestasi besar-besaran tentang doktrin Budhis dapat dilihat dan di rasakan melalui sejumlah aneka ragam karya artistik, ada kurang dari 1.460 relif naratif 1,300 diantaranya terpanjang daai lorong-lorong dan 160 sisanya terdapat di hidden foot (dasar/kaki candi yang tertutup tanah). Keseluruhan reliftersebut mengambil tempat sepanjang 2.300 meter dan menutup bidang seluas 1.900 meter persegi, di samping ini ada pula relief dekoratif, lalu masih ada lagi 324 ratna, 1.740 ornamen segi tiga, 100 gargotles (patung pancuran) dan 32 patung singa (Joesoef, 2015:48-49).

Dari uraian di atas bahwa Borobudur adalah salah satu warisan dunia yang tak ternilai hargannya yang mana Borobudur salah satu keajaiban dunia yang terdapat di indonesia, maka dengan alasan inilah penulis bermaksud untuk mengadakan penelitian dengan judul "Pemanfaatan Nilai Budaya Candi Borobudur Sebagai Sumber Pembelajaran Sejarah".

\section{B. METODE PENELITIAN}

Berdasarkan rumusan masalah, penelitian ini menggunakan metode deskriptif kualitatif. Sumber Data. Informan, Dokumen. Tempat penelitian di candi 
Borobudur dan SMA PGRI 1 Palembang. Teknik Pengumpulan Data: Wawancara Mendalam, Kajian Dokumen, Observasi Langsung. Teknik Cuplikan. penelitian ini menggunakan teknik cuplikan purposive sampling. Validitas Data. Validitas data sangat penting dalam proses pemaparan hasil penelitian, pembahasan dan penarikan simpulan. Dengan adanya validitas data triangulasi yang digunakan: triangulasi data, triangulasi metode.

\section{HASIL DAN PEMBAHASAN Hasil Penelitian \\ 1. Nilai Budaya Candi Borobudur Konsep Kosmologi}

Kosmologi merupakan cabang filsafat yang membicarakan asal mula dan struktur alam semesta, adapun masalah-masalah atau persoalan-persoalan kosmologi menurut $F$. Tailor adalah sebagai hubungan antara ruang dan waktu langsung menuju pada persoalan apakah ruang dan waktu sungguh-sungguh merupakan suatu hal yang terdapat diluar benda-benda dan peristiwa-peristiwa di dalamnya ruang dapat disamakan bagai sebuah jambangan yang di bagian lambungnya memuat seluruh dunia fisik.

Demikian pula halnya dengan waktu hanya saja waktu selalu bergerak cepat menghilang. Hal inilah yang di namakan teori absolut tentang ruang dan waktu, pada prinsipnya dapat dinyatakan bahwa kita tidak dapat membicarakan benda-benda hanya dalam arti spatial tetapi harus di dalam ruang, juga tidak di benarkan hanya sebagai temporal tetapi harus di dalam waktu Kosmologi tidak hanya mencakup kosmogoni tetapi juga kandungan dan organisasi alam semesta untuk aspek studi kkosmologi berbeda dengan studi tentang ilmu alam (fisiksa) kerena problem yang dihadapi kosmologi bersifat unigue, kita dapat mengadakan check terhadap generalisasi teori gravitasi misalnya dengan pengetahuan bahwa teori ini adalah mungkin untuk di terapkan pada fenomena alam yang berlainan karena sifat hakekatnya suatu teori kosmologi hanya dapat di aplikasikan untuk suatu sistem alam semesta saja (Hariyono, 2001:14-15).

Kosmologi Budha adalah dunia bawah merupakan tempat manusia yang masih di penuhi oleh keinginan dan hawa nasfu (Sulistyanto, 2014:1). Dapat disimpulkan bahwa kosmologi ialah salah satu kandungan alam semesta yanga sangat indah dan mempesona bagi semua masyarakat indonesia yang dapat melihat keindahannya.

\section{Bangunan Candi Borobudur}

Candi Borobudur disusun menggunakan batu andesit yang berbentuk persegi, bentuk struktur seperti pundan berundak yang semakin keatas semakin mengecil dengan empat buah tangga yang terdapat di setiap sisi mata angin (Timur, Selatan, Barat, dan Utara). Strukturnya terdiri atas sembilan teras berundak yang terdiri dari enam teras berdenah persegi dan tiga teras berdenah lingkaran, di antara bentuk teras tersebut terdapat lantai yang disebut plateua, candi Borobudur merupakan tiruan alam semesta yang terdiri dari tiga tingkatan secara vertikal, yaitu Kamadhatu, Rupadhatu, dan Arupadhatu (Depdikbud, 2014:4-5).

Kamadhatu adalah tingkat terendah dari tingkatan kosmologi Budha (simbol dunia hasrat). Kamadhatu pada candi Borobudur adalah bagian kakinya. Pada tahun 1885, J.W. ljzerman secara kebetulan menemukan kembali relief Karmawibhangga pada bagian kaki candi Borobudur. Profil candi Borobudur secara umum terdiri dari lapik, pelipit, ojief (sisi setengah genta), dan half round. Bagian kaki yang berbatasan langsung dengan tanah adalah lapik, sedangkan diatasnya adalah pelipit. Pelipit adalah tonjolan tersusun pada profil tubuh candi. Half round adalah bentuk setengah lingkaran. Ojief adalah bangunan kaki candi yang kontur penampangnya seperti sisi 
genta atau bentuk lonceng terbelah dua (Balai Konservasi Borobudur, 2016:21-22).

Rupadhatu yaitu tingkatan kedua dari tingkatan kosmologi Budhis yang mewakili dunia antara. Tingkatan ini adalah simbol unsur tak terwujud yang menggambarkan perilaku manusia yang sudah mulai meniggalkan keinginan duniawi, akan tetapi masih terikat oleh dunia nyata. Tubuh candi Borobudur terdiri dari susunan pagar langkan sebanyak lima buah yang membentuk empat buah lorong. Di atas pagar langkan I terdapat deretan relungrelung dengan kemuncak berbentuk buah keben, dan pagar langkan II, III, dan IV terdapat deretan relung-relung dengan puncak stupa-stupa kecil sebagai ornamennya. Di tengah-tengah dari tiap lorong pada keempat sisi bangunan candi Borobudur terdapat tangga yang menghubungkan masing-masing lorong pada tingkat-tingkat berikutnya. Pada pagar langkan pertama, susunan menyatu dengan kaki candi yang asli (Balai Konservasi Borobudur, 2016:28).

Arupadhatu merupakan bagian paling atas pada candi Budha/tiga teras teratas berundak berbentuk lingkaran. Arupadhatu adalah simbol dari unsur tak terwujud dan sebagai tanda dari tingkatan yang telah meniggalkan nafsu duniawi. Merupakan gambaran dunia tanpa rupa dan bentuk, lambang kesempurnaan abadi. Pada tingkat Arupadhatu, terdapat 3 baris stupa yang melingkari sebuah candi induk di pusatnya. Tiga teras teratas candi Borobudur ini telah dibongkar dan dipugar oleh Th. Van Erp pada pemugaran pertama. Sedangkan pada pemugaran kedua oleh pemerintah Indonesia yang bekerjasama dengan UNESCO, tingkat Arupadhatu tidak dipugar karena dianggap masih cukup baik dan stabil (Balai Konservasi Borobudur, 2016:35).

\section{Relief Candi Borobudur}

Relief biasanya dipahatkan pada sebagian besar bangunan candi. Relief pada candi Borobudur berisikan ajaranajaran keagamaan, ajaran kebajikan yang selayaknya dapat ditiru dan dilaksanakan oleh manusia di dunia. Terdapat tidak kurang dari 1460 adegan relief candi Borobudur. Pokok-pokok moral yang tertuang dalam relief candi Borobudur pada dasarnya adalah ajaran Budha. Relief dipahatkan pada dinding candi (Rupadhatu) dan pagar langkan seluas 2500 m2.

Ada dua kategori relief, yaitu relief cerita dan relief lepas. Relief cerita yaitu relief yang mengambarkan unsur cerita tertentu, sedangkan relief lepas yaitu relief yang tidak mengandung cerita atau hanya merupakan hiasan dekoratif saja (terdapat pada pagar langkan bagian luar pada pagar langkan lorong I).

Relief-relief pada Candi Borobudur yaitu:

a. Karmawibhangga. Relief Karmawibhangga terdapat pada kaki (Kamadhatu). Mengungkapkan tentang perbuatan manusia yang mengandung kebajikan maupun kejahatan, serta segala akibat dari perbuatan tersebut.

b. Lalitavistara. Relief Lalitavistara dipahatkan pada dinding utama tingkat I, menceritakan tentang kehidupan Sang Budha di Surga Tushita hingga menyampaikan khotbahnya yang pertama di Taman Rusa.

c. Jataka dan Avanada. Relief cerita Jataka dan Avadana dipahatkan pada dinding utama lorong tingkat I, dan pagar langkan tingkat I dan II. Jataka adalah kisah tentang sang Boddhisattva yang mengalami kelahiran berulang kali dalam berbagai wujudnya untuk membantu manusia mencapai jalan kebudhaan. Dalam kisah-kisah itu Sang Boddhisattva baik sebagai manusia maupun hewan selalu mencontohkan kepada kebenaran dan ajaran tentang dharma. Avadana adalah cerita yang 
sama dengan Jataka. Hanya saja pelaku utamanya bukan Sang Boddhisattva melainkan tokoh lain atau hewan biasa yang bukan jelmaan Boodhisattva.

d. Gandavyuha. Relief Gandavyuha dipahatkan pada dinding utama lorong tingkat II. Melukiskan pengembaraan Sudhana dari satu guru ke guru lain dalam upaya mencapai kebudhaan.

e. Bhadracari. Relief Bhadracari dipahatkan pada dinding utama pada bagian dalam setiap pagar langkan berisi relief cerita. Pada bagian atas pagar langkan berisi relung arca yang berisi arca Dhyani Budha. Sedangkan pada kemuncak pagar langkan I berbentuk keben dan kemuncak berbentuk stupa pada pagar langkan II V. Pada kemuncak pagar langkan juga dijumpai hiasan antefik, yaitu berupa pola dasar segitiga dan dihiasi dengan ukiran tumbuhan yang distilir (disamarkan), mempunyai fungsi untuk mengurangi kesan kaku yang diakibatkan oleh garis-garis mendatar pada candi (Balai Konservasi Borobudur, 2016:29-31). Relif yang dipahatkan pada candi Borobudur yang sekarang tertutup dikenai sebagi pelukisan atas naskah berbahasa Sansekerta yang ditemukan kembali oleh S. Levi, yaitu naskah mahakarmavibhanga naskah ini juga dihubungkannya dengan relif di candi ini (Balai Konservasi Borobudur, 2016:34).

Candi Borobudur mengandung pesan mulia yang digambarkan melalui relif-relif cerita yang di pahat di dinding candi dan dinding pagar langkan, candi Borobudur mempunyai 1.460 panil relif cerita yang tersusun dalam sebelas deretan mengitari bangunan candi, selain itu candi Borobudur memiliki relif dekoratif berupa relif hias sejumlah 1.212 panil, untuk membaca rangkaian relif dilakukan secara pradiksina yaitu mengelilingi candi searah jarum jam. Relif yang dibaca pertama kali dimulali dari sisi sebelah Timur, relif cerita di candi Borobudur (Balai konservasi Borobudur, 2014:6).

Relif yang dipahatkan di dinding candi sebenarnya mempunyai beberapa fungsi selain memperindah bangunan, fungsi lain itu adalah menyebarkan ajaran keagamaan melalui penggambaran visual, sehingga diharapkan dapat dengan mudah dimengerti oleh para pengamatnya, lalu penggambaran relif tersebut juga berfungsi untuk mengabadikan cerita keagamaan karena dalam bentuk media batu, adegan yang mengandung cerita dapat lebih lama bertahan daripada hanya diuraikan dalam bentuk media lontar karya sastra (Balai Konservasi Borobudur, 2016:96).

\section{Arca Candi Borobudur}

Arca yang menghiasi Borobudur mudah dikenal, karena selalu digambarkan berwujud manusia dan tidak pernah beranggota badan banyak. Pakaiannya selalu jubah seorang rahib, yang kelihatan hanya dua. a). Pakaian luar pada sikap duduk, bahu kanannya terbuka. b). Pakaian dalam tampak pada kakinya. di atas kepala ada semacam gelungan rambut (ushisha) dan rambut yang keriting melingkar ke arah kanan. Di antara kedua kening (alis mata) ada tonjolan kecil (urba), juga pada Bodhisatwa. Arca Budha yang berdiri sendiri tidak pernah memegang sesuatu di tangannya (kecuali dalam cerita pada relief, seperti Cakhyamuni memegang mangkuk minta-minta), tetapi tangannya bersikap tertentu (mudra) dan setiap mudra mempunyai arti tertentu pula. Mudra-mudra itulah yang dapat membedakan masingmasing Budha, sebab hal-hal yang lain semuanya sama, baik Dhyani maupun manushi Budha (terutama Cakhyamuni bermudara seperti Dhyani Budha. Di dalam relung-relung di atas pagar langkan tingkat pertama yang menghadap ke luar, terdapat arca-arca manusia Budha yang 
menjelmakan dirinya di dunia fana. Pada tiap-tiap arah, ditempati oleh masing-masing manusia Budha tertentu: Kanakamuni (Timur), Kacyapa (Selatan), Cakhyamuni (Barat), dan Maitreya (Utara). Jumlah ini ada 92 buah. Di dalam relung-relung yang mengelilingi tiga lorong terdapat DhiyaniBudha, masing-masing dapat dibedakan karena tempat dan sikap tangannya. Pada tiap tingkat sekeliling lorong terdapat 92 arca. Jadi keseluruhan arca di dalam relungrelung ini berjumlah berjumlah $3 \times 92=276$ buah Pada tingkat lima keliling lorong, terdapat arca Budha yang menghadap ke semua arah (keseluruhannya berjumlah 64 buah), ialah Dhyani Budha Wairocana yang, yang menguasai zenit dengan witarkamudra (sedang mengajar atau berbicara). Di atas telah dikemukakan, bahwa sistem atau susunan enam Dhiyani Budha. Jadi di atas lima Dhiyani-Budha yang telah diutarakan (yang menempati relung-relung pada tingkat II-V) ada Dhyani Budha yang keenam, yaitu Wajrasatwa dengan dharmacakramudra memutar roda darma-hukum atau ajaran kebenaran (Soetarno, 1987:94).

Arcar Budha pada tingkat rupadhatu terletak dalam relung terbuka bagian depannya. Arca tersebut digambarkan dalam posisi duduk bersila di atas padmasana dalam keadaan samadhi penuh. Relung-relung pada tingkat ini susun berjajar pada sisi luar pagar langkan. Sesuai dengan tingkat bangunan yang semakin tinggi letaknya dan semakin kecil ukuran. Maka pada langkan tingkat pertama terdapat 104 relung, pada tingkat ke 2 terdapat 104 relung, pada tingkat ke 3 terdapat 88 relung, pada tingkat ke 4 terdapat 72 buah, dan pada tingkat ke 5 terdapat 64 relung dengan demikian jumlah relung ada 432, dan sebanyak itu pula jumlah arca di dalamnya. Sistem pembuangan air hujan pada candi ini sangat diperhatikan. Tidak kurang dari 100 pancuran, yang disebut jaladwara, ditempatkan pada masing-masing sudut, mulai dari tingkat dari bawah sampai tingkat dari atas. Tiap ujung pancuran dihias indah sekali dengan pahatan-pahatan yang melukiskan kepala raksasa pada tingkat atas, dan makara pada tingkat paling bawah (Prasetyo, 1993:36).

Dalam bahasa Sanskerta arca, yang berarti gambaran arca dewa. Bera yang artinya perwujudan atau arca (dewa), dan vigraha yang berarti perpaduan, perwujudan (dewa) serta pratima yang berarti perwujudan jasmani seorang dewa yang dipuja oleh para bhakta. Bahkta adalah orang-orang yang berbakti atau memuja. Untuk lebih mendekati rasa ketuhanan, para bhakta kemudian menggunakan istilah tanu, yang berarti tubuh (dewa) dan rupa, yang berarti bentuk (dewa) yang menggunakan istilah tanu dan rupa mereka merasa puas, karena merasa lebih dekat dengan tuhan atau dewa yang dipujanya. Selain istilah tanu dan rupa dikenal pula kata vimba yang berarti pencerminan yang sama. Artinya kata vimba ini tercermin dalam suatu upacara yang dikenal sebagai upacara Durgapuja, yaitu suatu upacara untuk meminta keselamatan atau hal-hal yang berkaitan dengan keduniawian. Dalam upacara ini dilakukan upacara memandikan arca atau dewi yang terbuat dari batu atau dari tanah liat (Maulana, 1997:2).

\section{Nilai Budaya Pada Produk Budaya}

Pariwisata sebagia suatu kegiatan melibatkan orang banyak di dalam masyarakat yang masing-masing melakukan perkerjaan-pekerjaan tertentu, wisatawan sendiri yang melakukan perjalanan wisata perlu mengadakan persiapan-persiapan, ia harus memilih kedatangan wisatawan dengan megadakan kegiatan-kegitan yang sekiranya sesuai dengan motifsi wisatawan ada yang menyediakan angkutanorang lain mengadakan persiapan-persiapan agar kebututhan wisatawan akan makan, minum dan penginapan dapat dipenuhi ada yang, menjadi petunjuk jalan damn sebaginya (Prasetyo, 1993:21-22). 


\section{Nilai Budaya Candi Borobudur Berupa Pemakaian Nama Tokoh/Hotel/ Bangunan}

\section{Nilai Budaya candi Borobudur: Berupa Tempat perkantoran candi Borobudur}

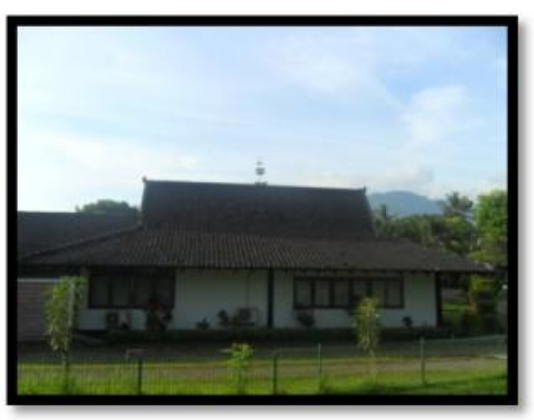

Tempat perkantoran yang ada di candi Borobudur ini adalah tempat para pegawai atau pengurus candi Borobudur yang bekerja selama candi Borobudur dibuka baik itu dari pagi hingga sampai malam hari. Pemanfaatan kebudayaan sebaga objek wisata memang sangat menjanjikan dalam visi tahun 2020 memprediksi bahwa wisata budaya akan merupakan salah satu diantara segmen pasar pariwisata di masa akan datang. Kiranya patut diingat bahwa ada semacam kekhawatiran antara manajemen kebudayaan termasuk juga alam dan kepariwisataan, dalam hal ini pariwisata, nilai budaya dan kelestariannya benda cagar budaya (BCB) (Balai Konservasi Borobudur, 2016:23).

Hotel merupakan bagian yang integral dari usaha pariwisata dan dapat dikatakan sebagai usaha akomodasi yang dikomersialkan untuk umum, fasilitasfasilitas hotel secara umum yang menghasilkan produk pelayanan jasa antara lain a. Kamar tidur tamu; b. Makan dan minum; c. Fasilitas pelayanan lain seperti, rekreasi,olahraga, loundry, penyewaan ruangan business centre. hotel adalah suatu jenis akomodasi yang mempergunakan sebagian atau seluruh bangunan untuk menyediakan jasa penginapan, makanan dan minuman serta jasa lainnya bagi umum, yang dikelola secara komersial (Muljadi, 2014:192-193).

Pariwisata budaya merupakan fokus kajian berbagai disiplin ilmu, mulai dari antropologi, ekonomi, sosiologi, geografi. Oleh sebab itu, pendekatan multidisiplin akan memudahkan kita untuk memahami perkembangannya diberbagai tempat. Ada dua pertanyaan penting yang perlu dijawab dalam pembangunan pariwisata budaya. Pertama, bagaimana kebijakan yang diambil mampu mendorong pengembangan dan konservasi budaya sehingga dapat dijadikan atraksi pariwisata? Kedua, bagaimana kebijakan pemerintah mampu mencegah degradasi budaya dan meningkatkan nilai ekonomi unit-unit kebudayaan melalui pembangunan pariwisata. Dua tema besar yang menjadi fokus perdebatan didalam kebijakan pengembangan pariwisata budaya tersebut masih sangat relevan dengan situasi pembangunan pariwisata Indonesia.

Pariwisata budaya memiliki nilai keuntungan ekonomi dan budaya yang saling melengkapi. Jika dikelola dengan cermat, ia ibarat dua sisi mata uang. Aset budaya dalam bentuk peninggalan sejarah, situs-situs sejarah dan beragam jenis kesenian sangat potensial untuk dijadikan sebagai komoditas ekonomi.

\section{Nilai Budaya candi Borobudur: Berupa tempat rumah makan candi Borobudur}

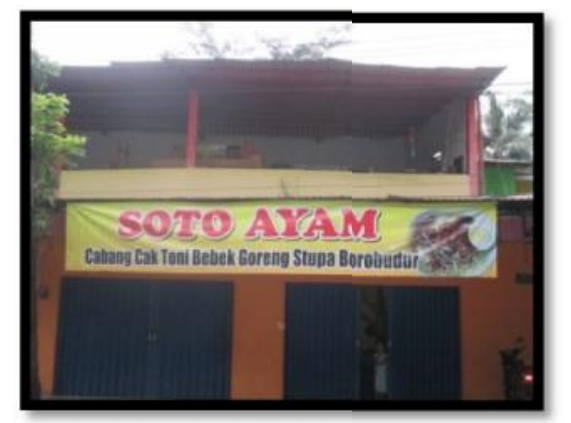

Rumah makan yang terdapat di Borobudur adalah rumah makan yang sangat strategis tempatnya karena rumah makan ini adalah salah satu budaya yang terdapat di candi Borobudur karena bisa meningkatkan pendapatan yang sangat 
banyak keuntungan dari candi Borobudur tersendiri, bukan hanya nilai Borobudur nya tetapi nilai dai rumah makanpun menjadi nilai budaya yang sangat bagus untuk perekonomian masyarakat candi Borobudur.

\section{Nilai Budaya candi Borobudur: Berupa Toko mebel.}

Toko mebel adalah toko yang mencakup perlengkapan rumah tangga seperti Kursi, Meja, dan Lemari yang mana dapat kita cari di toko mebel .

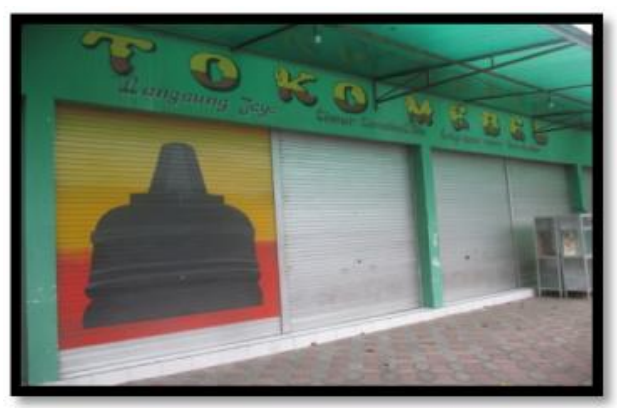

\section{Nilai Budaya candi Borobudur: Berupa topi}

Topi merupakan salah satu nilai budaya candi Borobudur yang mana pada nilai setiap budaya itu mempunyai nilainya masing-masing bagi masyarakat Borobudur yang mana hasil budaya tersebut dapat meningkatkan nilai perekonomian mereka.

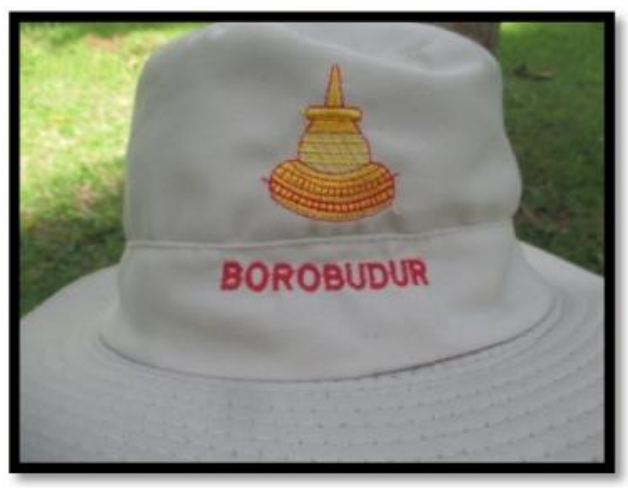

Nilai Budaya candi Borobudur: Berupa Stupa

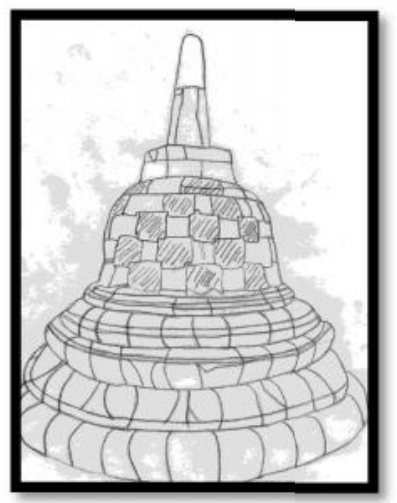

Stupa merupakan gambaran makrokosmos yang berkaitan dengan sang Budha adalah penguasa dunia sebagai cakrawatrin, ditandai dengan stupa ratnaTujuh manikam yaitu hastiratna (gajah) aswaratna (kuda) cinta mani (permata ,magic) striratna (istri atau permaisuri), grhpati (perdana mentri), dan parinayaka (panglima besar).

Kata Stupa berasal dari akar kata "stup" yang artinya mengakumulasi, berkumpul menjadi satu dalam istilah arsitektur stupa berarti monumen berbentuk piramida di atas relikui sang Budha. Jadi pada hakekatnya stupa adalah bangunan makam, kadang-kadang stupa dibuat dalam bentuk mini yang digunakan sebagai persembahan. stupa merupakan lambang Dharma, namun demikian tidak berarti setiap stupa berisi relikui (Haryono, 2011:9).

\section{Nilai Budaya candi Borobudur: Berupa mainan Kunci}

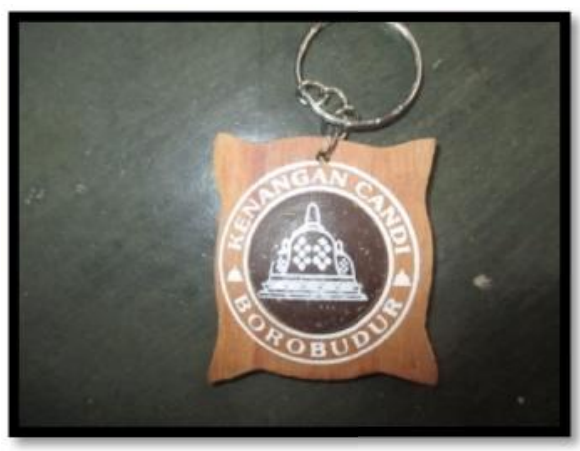


Mainan kuci adalah salah satu nilai budaya yang dibudayakan oleh warga candi Borobudur yang mana dapat meningkatkan nilai perekonomian warga Borobudur dan nilai budaya ini juga sebagai nilai budaya yang sangat banyak di beli oleh para wisatawan yang datang ke candi Borobudur dan membeli gantungan kunci tersebut sebagai oleh-oleh dari candi Borobudur.

\section{Nilai Budaya candi Borobudur : Berupa Gelang}

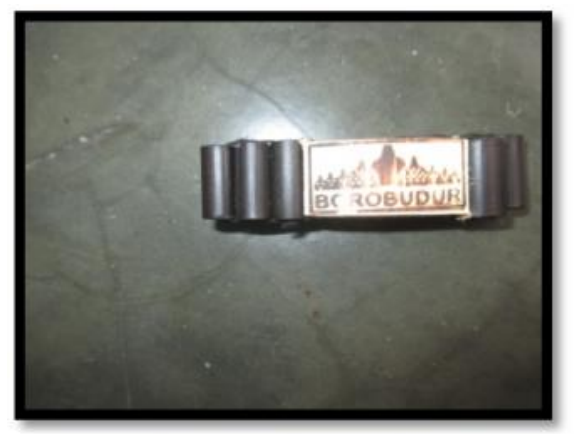

Gelang merupakan nilai budaya yang dibuat oleh warga candi Borobudur yang mana nilai budaya ini dibudayakan oleh warga Borobudur yang mana kerajinan ini dibuat oelh warga setempat guna untuk meningkatkan nilai perekonomian mereka serta memperkenalkan nilai budaya yang mereka buat dari hasil tangan mereka sendiri baik itu dari luar candi Borobudur, gelang juga dijual di daerah istimewa Yogyakarta.

\section{Nilai Budaya candi Borobudur: Berupa pulpen}

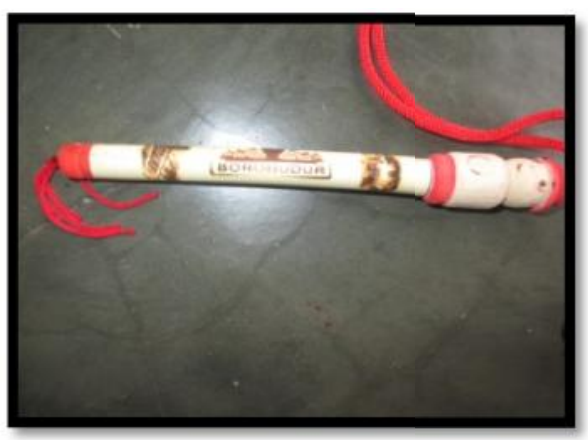

Pulpen merupakan hasil dari kebudayaan yang di hasilkan orang-orang magelang yang membuat kerajinan yang berupa pulpen, dengan demikian hasil budaya yang dihasilkan oleh warganya tersebut dapat meningkatkan mutu pembuatan kerajinan tersebut dapat meningkatkan wisatawan yang ingin datang ke magelang untuk melihat keindahan alamnya sekaligus memiliki hasil budaya yang di hasilkan.

\section{Nilai Budaya candi Borobudur: Berupa kipas}

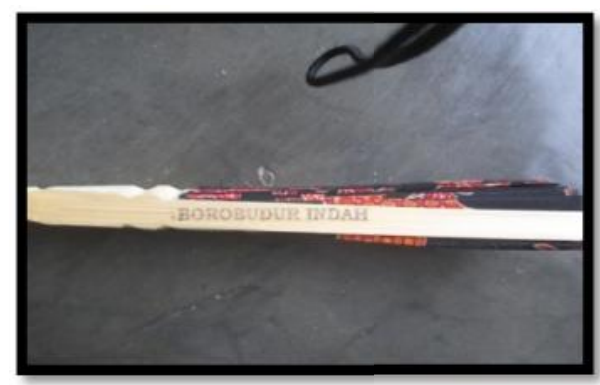

Kipas merupakan hasil budaya yang di asilkan warga Magelang cara membuat kipas ini relatif mudah karena bahan yang digunakan dalam pembuatan kipas tersebut tidaklah sulit bahan yang digunakan antara lailn : bambu, kain, benang, dan lem dengan bahan tesebut dapatlah membuat kipas tersebut, maka dari itulah masyarakat Borobudur sangat melestarikan hasil budaya tesebut.

\section{Nilai Budaya candi Borobudur: Berupa centong}

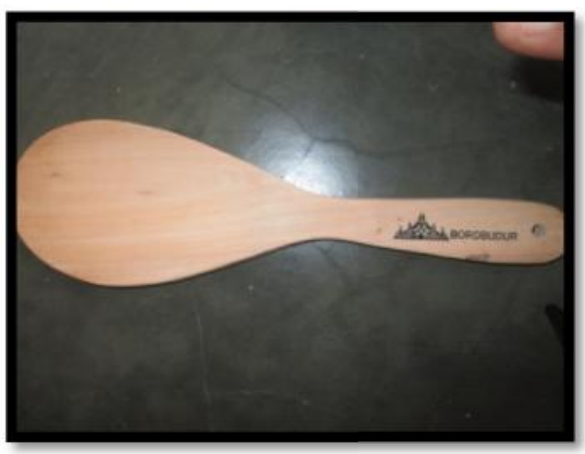


Centong merupakan alat yang digunakan untuk penyendok nasi yang terbuat dari kayu dan maka dari itu centong yang dihasilkan dari Magelang ini adalah centong yang dari kayu, ada juga yang terbuat dari plastik dengan demikian centong merupakan salah satu hasil karya dari Borobudur yang sangat banyak diminati oleh masyarakat Magelang dan sekitarnya, dengan adanya hasil budaya yang sangat menarik.

\section{Nilai Budaya candi Borobudur: Berupa Homestay}

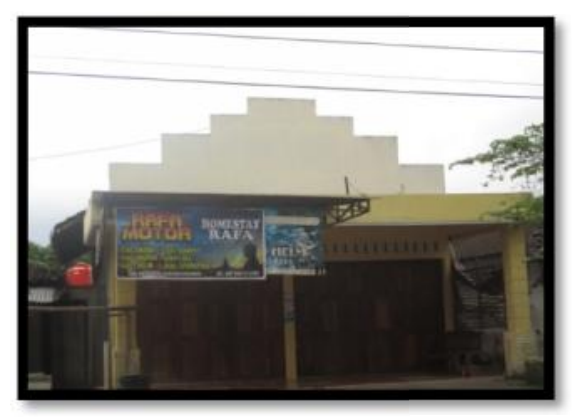

Homestay adalah salah satu tempat penginapan yang dibuat oleh masyarakat Borobudur dengan tujuan untuk menerima masyarakat asing yang ingn berkunjung di Borobudur dengan tujuan ingin menambah pendapatan mereka maka dari itulah masyarakat Magelang banyak sekali yang membuat rumah untuk para pengunjung yamg datang ke candi Borobudur ini, agar nilai budaya yang di miliki oleh masyarakat tersebut dapat dilestarikan.

\section{Pembahasan}

\section{Pemanfaatan Nilai Budaya Candi Borobudur Sebagai Sumber Pembelajaran Sejarah Dalam K13}

K13 merupakan strategi pengembangan kurikulum untuk mewujudkan sekolah yang efektif, produktif, dan berprentasi K13 merupakan paradigma baru pengembangan kurikulum, yang memberikan otonomi luas setiap satuan pendidikan, dan perlibatan masyarakat dalam rangka mengefektifkan proses belajar-mengajar disekolah. Otonomi diberikan agar setiap satuan pendidikan dan sekolah memiliki keleluasaan dalam mengelola sumber daya, sumber daya, sumber dana, sumber belajar dan menglokasinnya sesuai dengan prioritas kebutuhan, serta lebih tanggap terhadap kebutuhan setempat.

Candi Borobudur sangat efektif dan representative jika dimanfaatkan sebagai sumber pembelajaran karena di dalam komplek candi Borobudur selain pengajaran materi sejarah yang disampaikan dengan cara ceramah, diskusi, tanya jawab, dan tugas mandiri siswa juga menyaksikan gambar-gambar foto, benda-benda peninggalan yang digunakan pada peristiwa zaman dahulu. Siswa diberi kesempatan untuk melihat, mengamati, dan menanyakan langsung terhadap materi yang belum jelas. Hal itu memungkinan siswa untuk berpikir kreatif, menemukan konsep-konsep baru tentang materi, sehingga memudahkan siswa untuk mengerti dan memahami materi yang disampaikan dan tidak mudah begitu saja (hasil catatan wawancara Bapak Amiril Mukminin, S.Pd pada tanggal 8 Mei jam 09.30 WIB). Keberadaan pemanfaatan nilai budaya candi Borobudur sangat relevan dengan materi yang tercantum dalam kurikulum SMA. Hal ini dapat dilihat dari latar belakang peristiwa bersejarah. Berdasarkan Kurikulum Tingkat Satuan Pendidikan (K13) sejarah SMA, Relevansi antara arca Budha di candi Borobudur dengan Kurikulum sejarah SMA adalah sebagai berikut;

\section{Pemanfaatan nilai budaya candi Borobudur Sebagai Sumber Pembelajaran Sejarah di SMA PGRI 1 Palembang \\ Menurut tradisional dan klasik, dalam} segala keadaan tradisional, dan khususnya keadaan-keadaan pada asal mula arsitektur, bagan-bagan penataan sering didasarkan atas hal yang suci, karena religi 
dan ritual menjadi pusat (walaupun baganbagan lain juga memainkan peranan). Pandangan dunia masyarakat tradisional adalah yang memainkan peranan) pandangan dunia masyarakat tradisional adalah religius, maka lingkungan buatan yang mengkiaskan cita-cita harus mengkiaskan yang suci, karena hal itulah menunjukan cita-cita harus paling berarti. Kebanyakan bangunan tradisional, misalnya permukiman adalah gambaran duniawi dan citra surgawi yang mencakup poros bumi, pusar-pusar dunia, arah-arah pokok sifat bulat, sifat segi empat panjang, dan semuanya merupakan upaya untuk membedakan daerah yang suci, dan demikian juga manusiawi, serta dapat diami, dari kekacauan duniawi disekitarnya umpamanya. Pemukiman itu dianggap sebagai sebuah rumah raksasa dan denah rumah itu sebenarnya dapat disuperhiposekan pada suatu kerangka manusia dalam suatu posisi tertentu yang digunakan dalam penguburan. Dalam arsitektur tradisonal Hindu, ruang, waktu, dan zat adalah manifestasi dari pencipta, ruang kebendaan dan zat kebendaan menjadikan ruang ideasional terlihat: model kosmologisnya menekankan pada: (1) Kemurnian ritual di dalam rona; (2) Pusat dan keterpusatan hal terpenting secara sosial dan secara arsitektur; dan (3) Ruang ideasional yang diejawantahkan melalui lambang-lambang. Ruang diubah oleh lambang-lambang dan ritual-ritual sehingga sifat kedewaan jadi terlihat dan arsitektur disebut 'Wastu Vidya' ilmu persemayaman para dewa selain itu ragam seni hias bisa dijadikan sumber pembelajaran sejarah.

Sedangkan keberadaan candi Borobudur sangat relevan dengan materi yang tercantum dalam kurikulum terbaru yaitu K13 di mata pelajaran sejarah kelas XI semester genap adapun untuk lebih jelasnya sebagai berikut:

Kompentensi Inti: 1. Memahami, menerapkan dan menganalisis pengetahuan faktual, konseptual prosedural berdasarkan rasa ingin tahunya tentang ilmu pengetahuan, teknologi, seni budaya, dan humaniora dengan wawasan kemanusiaan, kebangsaan, ketenagraan, dan peradaban terkait fenomena dari kejadian serta menerapkan pengetahuan procedural pada bidang kajian yang spesifik sesuai dengan bakat dan minatnya untuk memecahkan masalah.

Kompentensi Dasar: 1.1. Menganalisis pengaruh perkembangan agama dan kebudayaan Hindu-Budha terhadap masyarakat di berbagai daerah Indonesia

Materi: Agama dan kebudayaan HinduBudha di Indonesia lahir dan berkembangnya agama dan agama HinduBudha, Proses masuk dan berkembangnya agama dan kebudayaan Hindu-Budha di Indonesia

Maka materi yang berkenaan dengan pemanfaatan nilai budaya candi Borobudur sebagai sumber pembelajaran sejarah dapat dijadikan sumber pembelajaran sejarah SMA kelas $X$ dan juga dapat dikembangkan dalam proses pembelajaran sejarah karena materi ragam seni hias pintu Borobudur (hasil catatan wawancara Bapak Amiril Mukminin, S.Pd pada tanggal 08 Mei jam 08.30 WIB).

\section{SIMPULAN}

Candi Borobudur adalah candi yang terbesar di Indonesia salah satu candi Agama Budha yang mana di setiap candi ini terdapat banyak arca Budha yang didalam Stupa tersebut dengan banyaknya stupa tersebut maka candi Borobudur sangat banyak sekali nilai budaya yang di hasilkan oleh candi Borobudur, dengan banyaknya nilai budaya yang dapat di manfaatkan oleh masyarakat candi tersebut adalah perkantoran, mebel, hotel, stupa, topi, gantungan kunci, centong, pulpen, yang dihasilkan oleh masyarakat candi Borobudur. Selain sebagai tempat nilai budaya candi Borobudur juga sebagai tempat Pariwisata yang mana pada setiap harinya candi Borobudur tidaklah sepi tetapi 
sangantlah banyak pengunjung yang datang ke candi Borobudur.

Nilai budaya yang terdapat di candi Borobudur sangatlah banyak nilai budayanya dikarenakan candi yang di temukan sekitar abad ke VII Masehi ini sangat banyak nilai budya oleh karena itulah pelestarian yang dihadapi sebagai warisan budaya menarik perhatian masyarakat dunia dan menggugah kepedulian serta upaya bersama dalam pelestariannya, selanjutnnya timbul kesadaran bahwa pelestarian warisan budaya tidak bisa hanya di bebankan kepada masyarakat lokal perlu usaha bersama agar dapat lebih menjamin kelestarian warisan budaya tersebut, warisan budaya yang ada di suatu tempat tidak hanya menjadi milik dari masyarakat setempat tetapi merupakan milik seluruh umat manusia termasuk tanggung jawab pelestariannya.

\section{DAFTAR PUSTAKA}

Balai Konservasi Borobudur. 2016. Kearsitekturan Candi Borobudur. Magelang: Balai Konservasi Borobudur.

Hariyono, Rudi. 2001. Tabir Misteri Jagad Raya. Surabaya. Putra Pelajar.

Joesoef, Daoed. 2015. Borobudur. Jakarta: Kompas.

Maulana, Ratnaesih. 1997. Ikonografi Hindu. Jakarta: Fakultas Sastra UI 1997.

Muljadi, Dkk. 2014. Kepariwisataan dan Perjalanan. Jakarta: PT Raja Grafindo Persada.

Rahardjo Supratino. 2005. Religi Dalam Dinamika Masyarakat. Banten.

Soetarno, 1987. Aneka Candi Kuno di Indonesia. Semarang: Dahara Prize Semarang.

Sulistyanto Bambang. 2015. Ragam Hias Candi-candi di Jawa. Yogyakarta: Kepelpres. 